\title{
Te reo Māori in classrooms Current policy, future practice
}

\author{
GEORGINA STEWART
}

\section{KEY POINTS}

- The great majority of Māori children develop their learning identities in English-medium primary classrooms. Encountering te reo Māori in the classroom helps Māori children feel they and their culture "belong" there.

- Policy for te reo Māori programmes in all classrooms, Māori-medium and English-medium, is set out in the document Tau Mai Te Reo. This signals a new unified approach, bringing all Māori-medium and English-medium schools under one language policy.

- It is important for schools to interrogate common myths about te reo Māori being an "inferior" language, and other associated outdated ideas.

- In the classroom, five main types of resources can best be used in combination for mutual support. People are the most valuable form of resource for te reo Māori in the classroom, but possibilities vary according to local conditions.

- All teachers can and should undertake to increase the amount and quality of te reo Māori in their classroom programme. A supportive classroom language policy and a teacher role as "learning facilitator" rather than "classroom expert" are ways to support positive change.

- Te reo Māori is a beautiful indigenous language that enhances any child's learning, and deserves the active support of all classroom teachers. 
This article is written for primary teachers who are not fluent in the Māori language (te reo Māori), about how and why te reo Māori can and should be used in the classroom. This article aims to help teachers understand the relevance of current policy documents, and to present useful guidelines on ways classroom practice can support the larger goals of the Ministry of Education, the government, and the nation as a whole, for ensuring a bright future for this beautiful indigenous language with which we have been entrusted.

\section{Introduction}

This article is for teachers who are not fluent speakers of the Māori language (te reo Māori), explaining how and why te reo Māori can and should be used in the classroom. This article focuses on policy and practice for te reo Māori teaching and learning in Englishmedium primary classrooms, where the classroom programme is based on the learning areas of The New Zealand Curriculum (Ministry of Education, 2007). The aim of this article is to help teachers better understand what lies behind the current policy documents, and to present some simple guidelines on including te reo Māori in classroom programmes.

\section{Current policy on te reo Māori in classrooms}

The range of schools in Aotearoa New Zealand has increased greatly since the reforms of the i980s, which were based in part on the concept of choice that is fundamental in marketised policies. In the school sector, the choice of schools supports the rights of Māori to an education in te reo Māori, which is one of the policy drivers for kura kaupapa Māori and bilingual programmes. Given the growth of the Māori-medium sector in recent decades, it could seem natural for teachers in English-medium primary classrooms to think it is not their role to teach te reo Māori, but this would be an incorrect assumption.

The current overarching policy or strategy for Māori education is presented in the booklet Ka Hikitia: Accelerating Success, 2013-20I7 (Ministry of Education, 2013b). A number of other policy documents sit under Ka Hikitia, the one most relevant to this discussion being Tau Mai te Reo: The Mãori Language in Education Strategy, 2013-2017 (Ministry of Education, 2013c). There are also documents for getting started with Ka Hikitia, including one aimed at primary schools (Ministry of
Education, 2013a). A key message in these documents is that all teachers in primary school classrooms are expected to support children's learning of te reo Māori. This point is reinforced by the whakatauki (proverbial saying) and translation, placed before the first section of Tau Mai Te Reo: "He waka eke noa: A canoe that we are all in with no exception" (Ministry of Education, 20I3c, p. 6).

Many Pākehā teachers could find this a struggle, because (from my personal observations over 50 years) not knowing the Māori language is a strong, if nonarticulated, aspect of Pākehā identity_especially prior to the last few decades. This attitude could be seen as showing respect, by leaving to Māori what is Māori. But there is also a rather large subterranean residue of the old evolutionist colonial myths, such as Māori language being an "inferior" language (Wetherell \& Potter, I992), associated with this stance. Even the most respectful attitude of non-engagement by Pākehā with te reo Māori reinforces the binary that is characteristic of our society - the hard-edged separation between Māori and Pākehā identities, which (I would argue) contributes to that part of the gap in education outcomes for Māori which cannot be explained by factors relating to economic poverty. But (admittedly confusingly) I would also argue that this binary difference is real and valuable, since it underpins Māori ethnic, linguistic, and cultural identities. Those who argue that this binary does not exist (any longer) often dismiss Māori rights to selfidentity in the process (see e.g. Rata, 20I2). So I think this is a matter that requires each of us to think long and hard about what we really think, and what we must do about it. The following paragraphs present some key policy messages to support these reflections.

Ka Hikitia clearly states the issue: "Māori students do much better when education reflects and values their identity, language and culture" (Ministry of 
Education, 2013b, p. 6). It is in primary English-medium classrooms that the great majority of Màori children develop their learning identities. Given the importance of language to cultural identity, Māori children need to encounter te reo Māori in their classroom to feel they and their culture "belong" there.

Tau Mai Te Reo covers much ground, from the history of te reo Māori in schools through to the present complex situation. It then outlines data on what is happening now, and a plan by which the Ministry proposes to work towards its goals for te reo Māori in education, and measure the success of the strategy. One of the most interesting aspects of this document is the way it brings all English-medium and Māori-medium schools together under one language policy. It looks across all types of classrooms for common characteristics of programmes that support the identity of Māori children as Māori. With this in mind, one key section of the document warranting closer inspection is the rubric for "Effective provision of te reo Māori in and through education" (Ministry of Education, 2013c, pp. 46-47). This two-page matrix gives six level descriptors for each of five "key evaluative components" of the rubric:
I. provision
2. teaching
3. content
4. iwi
5. responsiveness (p. 45).

The level statements for each of the rubric's five components seem to describe Māori-medium classrooms at the top, or "Highly effective" level, and the approach to te reo in many average English-medium classrooms at the lowest level, "Poor or detrimental" (p. 46). It is difficult to conceive how this could be otherwise, which begs the question, is it fair to put all classrooms on the same scale? This question presents a learning opportunity for the typical primary classroom teacher to whom this article is addressed. It can support the introspective, ethical, subjective learning required of teachers to help bring about a genuine change in attitude, as referred to above. To be ranked at the bottom of an unfair scale of measurement is a valuable, if uncomfortable, learning experience for many teachers. More important to discuss, however, are ways in which classroom teachers can move up the ladder of effectiveness. Of the five, the second and third components are most relevant to classroom practice, so the other three components (I, 4, and 5) will be dealt with first, before discussing the key evaluative goals related to 2 . teaching and 3 . content.

The first component of the rubric is provision, which refers to the access of Māori children to te reo Māori in their classroom. This policy message allows some teachers to feel as though they are "off the hook" and, to an extent, this attitude is warranted. Undeniably, in schooling regions such as Northland or the East Coast, where there are over 50 percent Māori children in primary classrooms, the requirement for a teacher to deliver an effective programme in te reo Māori is greater than for a teacher in a classroom with few or no Māori children. Clearly too, this goal will be impacted by factors over which a classroom teacher has little if any control, such as school policies, timetabling and syndicate plans, specialist teaching staff available, and the purchase of classroom teaching resources.

The fourth and fifth components of the rubric-iwi, and responsiveness - relate to aspects of relationships between schools and their Māori communities, thus linking back to more general Māori education policy matters, as addressed in Ka Hikitia and Tãtaiako (Ministry of Education, 20II), in which important ideas include "cultural intelligence" and CRP, or culturally responsive pedagogies (Berryman, SooHoo, \& Nevin, 2013).

Importantly for teachers, the second and third components of the rubric - teaching, and contentrelate to professional practice, where individual teachers have most agency, and which therefore deserve focused attention. The teaching goal is a measure of pedagogy in terms of the competence of teachers, and the goal of content relates to curriculum, in terms of the quality of language acquisition supported by the classroom programme. The teaching goal suggests a need for professional learning opportunities, while the content goal suggests demand for high-quality classroom resources. Some studies have found children complain of being given the same worksheets to do, year after year, in Māori Language Week (Jackman, 20I3). This is a specific anecdotal example of an ineffective practice under Tau Mai Te Reo. Clearly, for those teachers who are prepared to "pick up the mānuka", much more is possible, and, under the terms of this policy, now expected. Here, mānuka refers to the whakatauki used before the third section of Tau Mai Te Reo in which the rubric appears: "Kua takoto te mānuka: The leaves of the mānuka tree have been laid down", with a footnote explaining this as a reference to a "form of wero", and a proverb used "when being challenged, or you have a challenge ahead of you" (p. 43).

It is important that teachers feel supported in accepting this challenge. Appropriate programmes of professional learning and high-quality classroom resources are needed. These components have implications for schools and in-service professional learning, and also highlight the need for providers of pre-service or initial teacher education to boost to more credible levels the provision of opportunities in their programmes for new teachers to develop competence and confidence in delivering sound programmes of teaching and learning in te reo Māori. 


\section{So what should teachers do?}

Having thought about and accepted their own personal responsibility for teaching te reo Māori as part of their classroom programme, teachers need to work smart, and to draw upon the resources available to them as efficiently as possible. These resources fall under the following headings:

I) People: Here classroom practice merges with schoolcommunity relationships, since the best resource people for te reo Māori will be in the community. No rules can be given other than the need for ethical behaviour and sincerity in approaches made towards members of the school's "Māori community", however that nebulous term is interpreted. If a teacher or community person is employed to offer te reo lessons, the classroom teacher must stay in the room, modelling learning, and learning along with the children - the te reo programme should not be seen as "teacher release" time. Clearly, the potential to quickly improve the effectiveness of the te reo classroom programme through local resource people is immense, yet entirely dependent on the circumstances in each individual school.

2) Reference books and articles for teacher learning: As teachers, we need to review the history of our education system and of the relationship between Māori and Pākehā, in order to interrogate the social myths promulgated through schooling. Many fine books and articles re-examine the history of te reo Māori in schools, along with related sociohistorical events and philosophical debates. A list of recommended reading is given at the end of this article, not as a list of classroom resources, but to support teachers to undertake a personal programme of study and research into the theoretical and historical issues underlying the question of teaching and learning te reo Māori in English-medium primary classrooms.

3) Te reo Mãori material suitable for classroom use: There is a veritable wealth of pre-recorded material incorporating te reo Māori that is suitable for use in the primary classroom, from music, to television shows, to books, to interactive websites. Science, Social Sciences, Mathematics and Statistics, and Technology, as well as the more conventional art, music, drama and Health and Physical Education, are all learning areas that provide rich opportunities for making one's classroom practice more bilingual. The idea of teacher identity as being a "learning facilitator" rather than the "classroom expert" is also helpful. This idea suggests that the most important change required of the teacher is one of attitude and openness towards te reo Māori in the classroom. The words "more bilingual" remind us that "bilingual" covers a huge range of classroom environments, from almost no Māori to almost no English being used in the classroom. For most non-Māori primary teachers, there would be ample room to increase the content of te reo Māori in one's teaching programme. There may well be a place for a classroom policy that encourages children to use te reo Māori in their work.

4) Teacher-developed material, puzzles and games: Crosswords, word finds, Māori card games, and other language-based games using Māori are potent but easy ways to bring genuine use of bilingual skills into the classroom, and relate learning in te reo Màori to the exact topics being used, which could be specific to the local area or school context.

5) EOTC (education outside the classroom) or field work: Here the classroom goes to the community, complementing I above, where local people come into the classroom. Becoming involved in the life of the local Māori community — for example, visiting a local marae or significant site to local iwi-will naturally support and enhance all the other types of resources above. Programmes including this type of learning experience offer the richest opportunities for supporting Māori identity, language, and culture in authentic learning contexts.

Clearly, the first and last of these types of resources are the most variable, about which little more can be said. Teachers in classrooms with few or no Māori children are less likely to succeed in implementing these relationshipbased resources, and may be restricted to more conventional classroom resources, that is, types 3 and 4 . But all five resource types are mutually reinforcing, in the sense that efforts made to incorporate more than one at a time will be synergistic. For example, when teachers are seen making efforts to incorporate or facilitate the use of te reo Māori in their classrooms, community help and involvement is far more likely to be forthcoming.

There is wide support amongst non-Māori for the efforts being made to ensure that te reo Māori, which has been recognised as being endangered for nearly half a century, does not become an extinct indigenous language. Strange alliances sometimes happen between opposite ends of the political spectrum, for there is no doubt that te reo Māori, associated with famous national icons such as the All Black haka, is a key part of the unique New Zealand "brand" of huge economic value in the global marketplace. The Aotearoa New Zealand government is well aware that to lose te reo Māori would be to lose face on the world stage. More importantly, te reo Māori is key to Māori identity and for understanding te ao Māori (the Māori world). Te reo Māori is a special taonga tuku iho (inherited treasure) that is important for connecting us to our Māori ancestors, ngā tūpuna mātua. Te reo Māori allows me as a speaker to think otherwise than in English: it embodies and encloses a unique worldview that has value as a framework of understandings associated with a range of tropes, metaphors, and concepts, including 
tapu, mana, utu, whakapapa, the cosmogenic narratives, and the wisdom expressed in whakataukī, such as those discussed above (Patterson, 1992; Salmond, 1985). Te reo Māori is a beautiful rich language that enhances any child's learning, and which deserves the active support of every classroom teacher in this country.

\section{Conclusion}

Now more than ever before, primary classroom teachers are being expected to deliver a credible classroom programme of teaching and learning in te reo Māori-an expectation that presents considerable challenge to many teachers. Current policy makes it clear that the future survival of te reo Māori depends on all teachers, and responsibility for te reo Māori in the education system must not be delegated solely to the Māori-medium sector. The acceptance in national policy of the right of Māori children to learning experiences in te reo Māori in their classroom means that getting serious about teaching and learning te reo Māori is no longer an optional extra. While policy lays this challenge at the feet of the classroom teacher, it is only fair that teachers, in turn, challenge the Ministry of Education and the national education system to provide high-quality professional learning programmes and classroom resources to support the larger goal of ensuring that the future of te reo Māori, our unique national indigenous language, remains secure.

\section{Selected further reading list}

Curnow, J., Hopa, N., \& McRae, J. (Eds.). (2002). Rere atu, taku manu! Discovering history, language and politics in the Mãorilanguage newspapers. Auckland: Auckland University Press.

Durie, M. H. (2005). Ngā tai matatū: Tides of Mãori endurance. Melbourne: Oxford University Press.

Harlow, R. (2005). Māori: Introduction. In A. Bell, R. Harlow, \& D. Starks (Eds.), Languages of New Zealand (pp. 59-66). Wellington: Victoria University Press.

Macfarlane, A. H. (2004). Kia hiwa ra! Listen to culture-Mãori students' plea to educators. Wellington: New Zealand Council for Educational Research.

Marsden, M. (2003). The woven universe: Selected writings of Rev. Mãori Marsden (T. A. C. Royal Ed.). Otaki: The Estate of Rev. Māori Marsden.

May, S. (2012). Language \& minority rights: Ethnicity, nationalism and the politics of language (2nd ed.). New York: Routledge.

Mulholland, M. (2006). State of the Mãori nation. Auckland: Reed.

Patterson, J. (200o). People of the land: A Pacific philosophy. Palmerston North: Dunmore Press.

Penetito, W. (20Io). What's Mãori about Mãori education? Wellington: Victoria University Press.
Pere, R. R. (1994). Ako: Concepts and learning in the Mãori tradition. Wellington: Te Kohanga Reo National Trust Board.

Rewi, P. (20I3). He ora, he orotītanga: Māori language—safe or endangered? In S. Katene \& M. Mulholland (Eds.), Future challenges for Mãori: He körero anamata (pp. IOI-II3). Wellington: Huia.

Salmond, A. (1991). Two worlds: First meetings between Mãori and Europeans $1642-1772$. Auckland: Viking Penguin.

Salmond, A. (1997). Between worlds. Auckland: Viking Penguin.

Selby, R. (1999). Still being punished. Wellington: Huia.

Smith, L. T. (2012). Decolonizing methodologies: Research \& indigenous peoples (2nd ed.). London: Zed Books.

\section{References}

Berryman, M., SooHoo, S., \& Nevin, A. (Eds.). (2013). Culturally responsive methodologies. Bingley, UK: Emerald Group.

Jackman, M. (2013). Te reo tamariki: Children talk about learning Mãori. Unpublished BEd (Hons) thesis, The University of Auckland, Auckland.

Ministry of Education. (20II). Tãtaiako: Cultural competencies for teachers of Māori learners. Wellington: Author. Retrieved from http://www.teacherscouncil.govt.nz/required/tataiako.stm.

Ministry of Education. (2013a). Getting started with ka hikitia: Accelerating success, 2013-2017: Primary education. Retrieved from http://www.minedu.govt.nz/-/media/MinEdu/Files/ TheMinistry/KaHikitia/KaHikitiaAcceleratingSuccess/ KHPrimary.pdf

Ministry of Education. (2013b). Ka hikitia: Accelerating success, 2013-2017. Wellington: Author.

Ministry of Education. (2013c). Tau mai te reo: The Mãori language strategy in education, 2013-2017. Wellington: Author.

Patterson, J. (1992). Exploring Maori values. Palmerston North: Dunmore Press.

Rata, E. (2012). Theoretical claims \& empirical evidence in Māori education discourse. Educational Philosophy and Theory, 44(Io), I060-I072. doi: I0.IIII/j.I469-58I2.20II.00755.x

Salmond, A. (1985). Māori epistemologies. In J. Overing (Ed.), Reason and Morality. London and New York: Tavistock Publications.

Wetherell, M., \& Potter, J. (1992). Mapping the language of racism: Discourse and the legitimation of exploitation. New York: Harvester Wheatsheaf.

Georgina Stewart (ko Whakarārā te maunga, ko Matauri te moana, ko Ngāti Kura te hapū, ko Ngāpuhi-nui-tonu te iwi) has 20-plus years of experience as a teacher, curriculum and resource developer in English-medium and Māori-medium schools. Georgina works in Te Kura o Te Puna Wānanga in the Faculty of Education, The University of Auckland, and is based at the Tai Tokerau Campus in Whangarei. 